\title{
Variations in autologous neutralization and CD4 dependence of b12 resistant HIV-1 clade C env clones obtained at different time points from antiretroviral naïve Indian patients with recent infection
}

\author{
Rajesh Ringe, Madhuri Thakar, Jayanta Bhattacharya*
}

\begin{abstract}
Background: Limited information is available on HIV-1 Indian clade C sensitivities to autologous antibodies during the course of natural infection. In the present study, a total of 37 complete envelope clones (Env) were amplified at different time points predominantly from the plasma of five Indian patients with recent HIV-1 infection and envelope-pseudotyped viruses were examined for their magnitude of sensitivity to autologous plasma antibodies during natural course of infection.
\end{abstract}

Results: Variable low levels of neutralization were consistently detected with contemporaneous autologous plasma. In contrast to clade B and African clade C HIV-1 envelopes, Env clones obtained from four patients were found to be resistant to lgG1b12. The majority of the Env clones were resistant to $2 \mathrm{G} 12$ and 2F5 due to the absence of the minimal motifs required for antibody recognition, but were sensitive to 4E10. Nonetheless, Env clones from one patient were found to be sensitive to 2G12, atypical for clade C, and one Env clone exhibited unusual sensitivity to 17b, suggesting spontaneous exposure of CD4i epitopes. Phylogenetic analysis revealed that Env clones were closely clustered within patients. Variation in the potential N-linked glycosylation pattern also appeared to be different in patients over the course of infection. Interestingly, we found that the sensitivity of Envs to contemporaneous autologous NAbs correlated positively with increased sensitivity to soluble CD4 and inversely with anti-CD4 antibody and Envs with increased NAb sensitivity were able to efficiently infect HeLa cells expressing low CD4.

Conclusion: Our data showed considerable variations in autologous neutralization of these early HIV-1 clade C Envs in each of these patients and indicate greater exposure to CD4 of Envs that showed increased autologous neutralization. Interestingly, Env clones obtained from a single patient at different time points were found to retain sensitivity to b12 antibody that binds to CD4 binding site in Env in contrast to Envs obtained from other patients. However, we did not find any association between increased b12 sensitivity of Envs obtained from this particular patient with their degree of exposure to CD4.

\section{Background}

Induction of broadly neutralizing antibodies (NAbs) against diverse strains of Human Immunodeficiency Virus Type 1 (HIV-1) remains an important goal for vaccine development [1-3]. Major obstacles are the

\footnotetext{
* Correspondence: jbhattacharya@nariindia.org

Department of Molecular Virology, National AIDS Research Institute, Indian Council of Medical Research, G-73 MIDC, Bhosari, Pune-411026, India
}

remarkable sequence variability of the envelope glycoproteins (Env) and the masking of critical neutralizing epitopes by $\mathrm{N}$-linked glycans and other structural and steric constraints [4-6]. Most HIV-1-infected individuals mount a strong autologous NAb response within the first 6 to 12 months of infection that is highly specific for the subject's transmitted/founder virus. The response generally broadens after several years of infection, where in approximately $10-20$ percent of cases the antibodies 
exhibit considerable breadth of neutralization against diverse strains [7-15].

HIV-1 entry is mediated by binding of trimeric gp 120 spikes to CD4 receptor that in turn exposes coreceptor binding sites and facilitates fusion of viral and cell membrane [16]. NAbs bind to exposed epitopes on Env trimers and thereby compromise HIV-1 entry $[17,18,6,19]$. The discovery of broadly neutralizing monoclonal antibodies (MAbs) from HIV-1-infected patients with the ability to neutralize diverse primary HIV-1 isolates [20-23], suggested that there are indeed vulnerable epitopes on the functional Env trimer [24]. Thus, MAb IgG1b12 binds the CD4-binding site (CD4bs) of gp120 [25] and neutralizes more than $50 \%$ of HIV-1 clade B and approximately $30 \%$ of non-clade B viruses [26,27]. Although many neutralization epitopes can be masked by $\mathrm{N}$-linked glycans, one MAb, $2 \mathrm{G} 12$ [28,29], binds to specific glycan residue and neutralizes many clade $\mathrm{B}$ isolates but has limited breadth against non-clade B isolates $[26,30,31]$. In addition, highly conserved sequences [32] in the coreceptor binding site (also known as CD4induced or CD4i region) are potential targets for virus neutralization [33-36]. Thus, antibodies mimicking prototype MAb 17b show significant virus neutralization after triggering gp120 with soluble CD4 (sCD4) [24]. Apart from epitopes in gp120 recognized by broadly neutralizing MAbs, the membrane proximal external region (MPER) in gp41 is vulnerable to NAbs and found to be a target of three well characterized MAbs 2F5, 4E10, and Z13 [37-39]. Antibodies targeting the MPER of gp41 neutralize HIV-1 by blocking viral fusion with the cell membrane and thereby preventing viral entry [40]. 59). Interestingly, these types of antibodies are rarely detected during natural infection $[22,41,42]$.

Being highly variable, Env remains a major target of the NAb response in HIV-1-infected individuals; thus, Env-driven antibodies have been shown to neutralize autologous virus variants moderately over time $[12,13,43,44]$, followed by rapid escape from neutralization. Autologous NAbs appear to be directed to variable regions of gp120 and are influenced by the pattern of surface Env glycosylation that varies widely among HIV1 strains $[9,10,44-52]$. These data indicate that despite a limited role for autologous NAbs in the control of viremia, the antibodies exert selection pressure on Env early in infection. In the case of HIV-1 clade B, the V1, V2 and V3 domains have also been shown to mediate CD4 independence, cellular tropism and receptor utilization in addition to neutralization sensitivity [49,53-65].

HIV-1 clade $C$ is the dominant genetic subtype circulating in India, Sub-Saharan Africa and China [66-70]. Though much information on autologous NAbs against HIV-1 African clade $C$ is available $[9,10,42,49,50,52,71,72]$, very limited information is available on the neutralization properties of subtype C HIV-1 in India. Current evidence suggests that sequences for the Indian HIV-1 clade C Env and other genes such as gag and nef form a monophyletic lineage and segregate separately as a sub clade within the more diverse subtype $C$ strains from Africa [69,73-77]. Recently, Kulkarni et al [27] demonstrated that newly transmitted Indian Envs are antigenically complex despite close genetic similarity. In this paper, we examined the $\mathrm{NAb}$ response in subtype C HIV-1-infected individuals in India by using Env clones amplified from uncultured peripheral blood mononuclear cells (PBMC) at the baseline, and plasma at the follow up visits of five recently infected subjects and assessed autologous NAbs at different time points for one year. We found that patient Envs varied considerably in their sensitivities to their autologous plasma antibodies and differed in their susceptibilities to MAbs, indicating distinct mechanisms of autologous neutralization and antibody specificities in these patients.

\section{Results}

\section{Genetic properties of clade $C$ env clones}

Study subjects are described in Table 1. More than one env clones was obtained from each of five recently infected HIV-1 positive individuals from India at a baseline visit and 6 and 12 months later except for subject IVC5, for whom the last visit was at 24 months (Table 2). Env clones from the baseline visit were obtained from infected PBMC DNA whereas for follow up visits, env was amplified from plasma viral RNA. Phylogenetic analyses of the complete gp160 amino acid sequences revealed that the Env clones were indeed subject specific (Figure 1), with intra-clonal genetic divergences between

Table 1 Patient details

\begin{tabular}{|c|c|c|c|c|c|c|c|c|}
\hline \multirow[b]{2}{*}{ Patient ID } & \multirow[b]{2}{*}{ Mode of Transmission } & \multirow[b]{2}{*}{ Year of Infection } & \multicolumn{3}{|c|}{ Plasma HIV-1 RNA (copies/ml) } & \multicolumn{3}{|c|}{ CD4 count (cells/mm3) } \\
\hline & & & Baseline & F1 (moths) & F2 (months) & Baseline & F1 (months) & F2 (months) \\
\hline NARI-IVC-2 & Heterosexual & 2008 & 8400 & $3070(6)$ & $17700(12)$ & 479 & $503(6)$ & $135(12)$ \\
\hline NARIIIVC-3 & Heterosexual & 2006 & 5380 & $29700(6)$ & $15700(12)$ & 592 & $499(6)$ & $477(12)$ \\
\hline NARI-IVC-4 & Heterosexual & 2006 & 37800 & UD (6) & UD (12) & 328 & $374(6)$ & $402(12)$ \\
\hline NARIIIVC-5 & Heterosexual & 2006 & 1410 & $9040(6)$ & $48600(24)$ & 606 & $619(6)$ & $427(24)$ \\
\hline NARI-IVC-11 & Heterosexual & 2007 & 33400 & $11900(6)$ & $17300(12)$ & 552 & $693(6)$ & $590(12)$ \\
\hline
\end{tabular}

UD: undetermined 
Table 2 Genetic properties of patient Env clones

\begin{tabular}{|c|c|c|c|c|c|c|c|}
\hline Patient ID & Clone ID/Follow up Schedulet & Source & gp120 length & gp41 length & PNLG sites & Net V3 loop charge & CoR usage \\
\hline & 2.J8/B & PBMC & 466 & 352 & 25 & 3 & CCR5 \\
\hline & 2.J9/B & PBMC & 466 & 352 & 26 & 3 & CCR5 \\
\hline & 2-3.J4/F1 & PLASMA & 465 & 352 & 30 & 3 & CCR5 \\
\hline \multirow[t]{6}{*}{ NARI-IVC2 } & 2-3.J7/F1 & PLASMA & 466 & 352 & 29 & 3 & CCR5 \\
\hline & $2-3 . J 17 / F 1$ & PLASMA & 460 & 352 & 28 & 3 & CCR5 \\
\hline & 2-3.J18/F1 & PLASMA & 465 & 352 & 30 & 3 & CCR5 \\
\hline & 2-5.J3/F2 & PLASMA & 466 & 345 & 31 & 3 & CCR5 \\
\hline & $2-5 . J 11 / F 2$ & PLASMA & 465 & 352 & 29 & 2 & CCR5 \\
\hline & 3.J16/B & PBMC & 466 & 352 & 27 & 5 & CCR5 \\
\hline \multirow[t]{8}{*}{ NARI-IVC3 } & 3-3.J9/F1 & PLASMA & 459 & 352 & 28 & 5 & CCR5 \\
\hline & $3-5 . J 25 / F 2$ & PLASMA & 458 & 352 & 29 & 4 & CCR5 \\
\hline & 3-5.J38/F2 & PLASMA & 463 & 352 & 31 & 3 & CCR5 \\
\hline & 4.J2/B & PBMC & 462 & 352 & 30 & 3 & CCR5 \\
\hline & 4.J22/B & PBMC & 462 & 352 & 30 & 3 & CCR5 \\
\hline & 4.J27/B & PLASMA & 461 & 352 & 29 & 3 & CCR5 \\
\hline & 4-2.J41/F1 & PLASMA & 458 & 352 & 27 & 2 & CCR5 \\
\hline & 4-2.J45/F1 & PLASMA & 460 & 345 & 27 & 2 & CCR5 \\
\hline \multirow[t]{10}{*}{ NARI-IVC4 } & 4-2.J42b/F1 & PLASMA & 464 & 345 & 27 & 2 & CCR5 \\
\hline & 4-2.J45b/F1 & PLASMA & 459 & 345 & 26 & 2 & CCR5 \\
\hline & 4-2.J46b/F1 & PLASMA & 464 & 345 & 28 & 2 & CCR5 \\
\hline & 4-2.J47b/F1 & PLASMA & 459 & 345 & 27 & 2 & CCR5 \\
\hline & 4-5.J5/F2 & PLASMA & 455 & 345 & 28 & 2 & CCR5 \\
\hline & 5.J41/B & PBMC & 472 & 351 & 29 & 2 & CCR5 \\
\hline & 5-3.J2/F1 & PLASMA & 461 & 351 & 26 & 3 & CCR5 \\
\hline & 5-3.J4/F1 & PLASMA & 472 & 351 & 29 & 3 & CCR5 \\
\hline & 5-3.J5/F1 & PLASMA & 461 & 362 & 30 & 3 & CCR5 \\
\hline & 5-3.J9/F1 & PLASMA & 472 & 351 & 29 & 3 & CCR5 \\
\hline \multirow[t]{7}{*}{ NARI-IVC5 } & 5-4.J16/F2 & PLASMA & 464 & 351 & 31 & 3 & CCR5 \\
\hline & 5-4.J18/F2 & PLASMA & 475 & 351 & 30 & 4 & CCR5 \\
\hline & 5-4.J22/F2 & PLASMA & 464 & 351 & 28 & 3 & CCR5 \\
\hline & 5-4.J49/F2 & PLASMA & 475 & 351 & 30 & 3 & CCR5 \\
\hline & 11.J25/B & PBMC & 461 & 352 & 27 & 4 & CCR5 \\
\hline & 11.J28/B & PBMC & 461 & 352 & 27 & 4 & CCR5 \\
\hline & 11-3.J3/F1 & PLASMA & 458 & 352 & 28 & 4 & CCR5 \\
\hline \multirow[t]{3}{*}{ NARI-IVC11 } & 11-3.J9/F1 & PLASMA & 457 & 352 & 27 & 4 & CCR5 \\
\hline & 11-3.J16/F1 & PLASMA & 457 & 352 & 26 & 4 & CCR5 \\
\hline & 11-5.J12/F2 & PLASMA & 461 & 352 & 28 & 3 & CCR5 \\
\hline
\end{tabular}

$\dagger \mathrm{B}=$ Baseline sample; $\mathrm{F} 1=$ First Follow up and F2 = Second follow up.

Env clones obtained from the same subject but at different time points indicated ongoing viral evolution. All Envs possessed low net V3 loop charge, a conserved GPGQ motif (Additional file 1: Figure S1) and were found to be CCR5 tropic (Table 2). Except for patients IVC 3 and IVC 4, no significant variation in total $\mathrm{N}$ linked glycosylation sites (PNLG) was found at the three time points sampled (Figure 2); the number of PNLG varied between 25-31 (Table 2). Median gp160 lengths varied between patients; however they did not differ significantly between clones obtained from the same patient at different times (Figure 3). Although there were no major differences between the variable loops of the patient-specific envelope clones obtained at different time points, Env clones 3-3.J9, 3-5.J25 and 5-4.J49, 5-4. J16 amplified from patients IVC 3 and IVC 5 were 


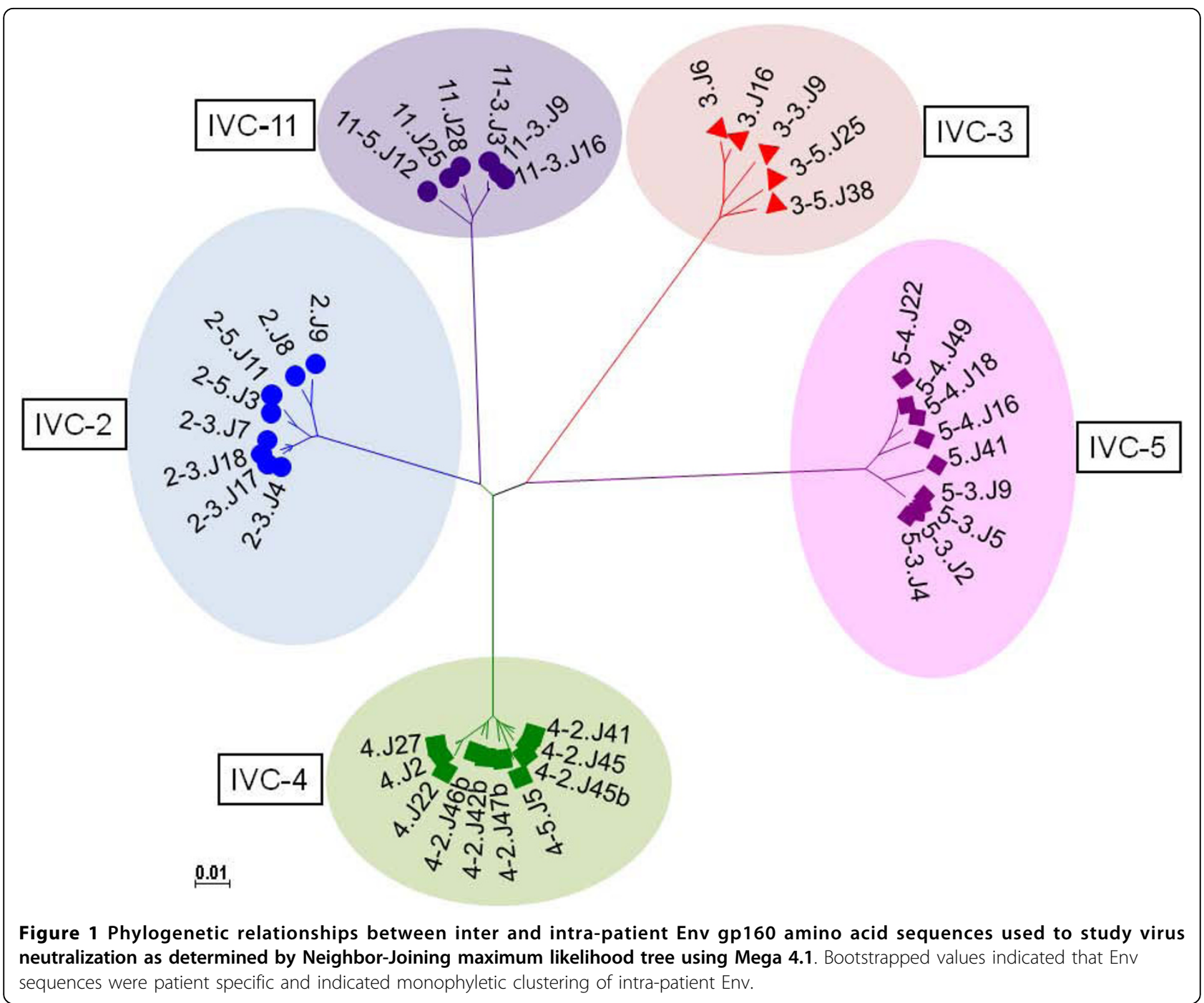

found to have shorter V1 and V2 loops compared to the contemporaneous Env clones (Additional file 1: Figure S1).

\section{Neutralization sensitivity of clonal Envs to autologous plasma varied between study subjects}

We next assessed the autologous neutralization of Env clones amplified at three different time points from each of five subjects. All five subjects mounted a moderate $\mathrm{NAb}$ response against their early viruses obtained at the baseline except patient IVC2; however this phenotype varied with respect to contemporaneous plasma antibodies (Table 3 ). Surprisingly, only $1 / 8$ clones from subject IVC-2 was neutralized by the plasma samples obtained at later time points, whereas a few (3/8) Env clones were neutralized by the contemporaneous plasma. Thus, while the autologous NAb response to early Env clones improved over time in four subjects, it diminished over time in one subject. This observation was correlated with a gradual decline in CD4, indicating that autologous NAb possibly has selected the fittest Env variants capable of faster disease progression in this particular patient. The majority of the Envs obtained from follow up visits were resistant to contemporaneous autologous plasma antibodies indicating rapid escape of viral variants. The persistence of a few sensitive Envs such as 33.J9/F1, and 4-2.J45 during this period of infection despite mounting humoral immune pressure may indicate that these Env variants had adapted to sustain such immune pressure possibly through certain compensatory changes in Env sequence and retained their sensitivities to autologous neutralizing antibodies.

\section{Neutralization phenotype of the Envs as assessed with common neutralizers}

To test if the Envs obtained from patients at different time points varied in their sensitivities to common broadly neutralizing MAbs, pseudotyped viruses carrying 


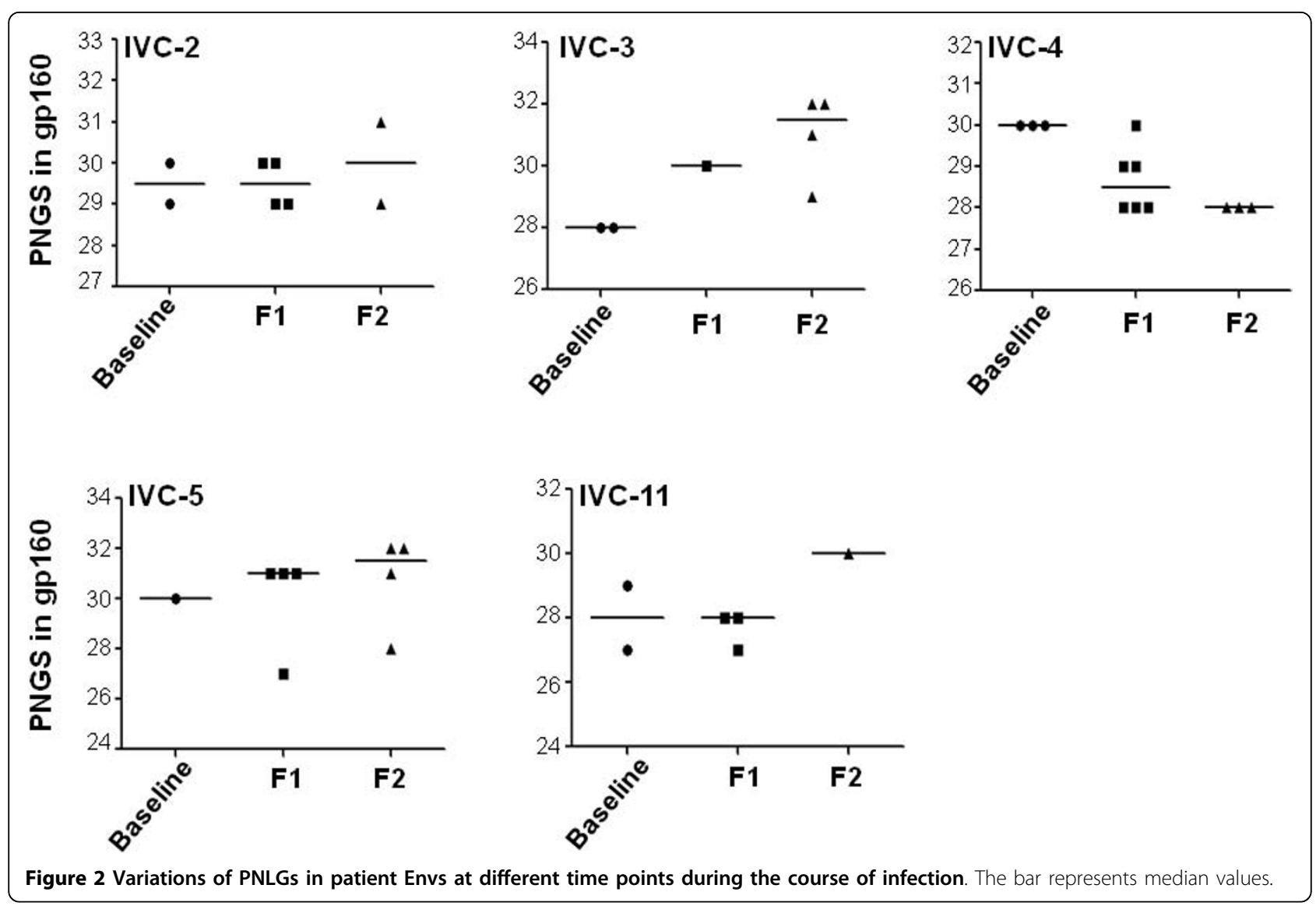

patient Envs were tested in neutralization assays with sCD4 and five MAbs (b6, IgG1b12, 2 G12 targeting gp120 and 2F5, and 4E10 targeting gp41). As shown in Table 4 the majority of Env clones were sensitive to $\mathrm{sCD} 4$ at concentrations ranging from 0.1 to $6.66 \mu \mathrm{g} / \mathrm{ml}$. The pseudoviruses that required excess $(>6.66 \mu \mathrm{g} / \mathrm{ml})$ sCD4 for $50 \%$ neutralization were considered as resistant in our study. Consistent with the earlier report [27] all Env variants were resistant to $2 \mathrm{G} 12$ except those obtained from IVC-3 patient and this resistance was associated with the absence of PNLG at position 295 (HXB2 numbering) at the N-terminal base of V3 loop. The sensitivity of IVC-3 env clones was due to the presence of N295, atypical of clade C. In contrast to clade $B$ and African clade $C$ viruses [10,26], envelopes from patient IVC 3, 4, 5, 11 were found resistant to IgG1b12. This observation of b12 resistance of the India clade Envs is in line with that reported by Kulkarni et al [27]. As with the MPER-specific MAbs, all the Envs were resistant to $2 \mathrm{~F} 5$ at the highest concentration tested (Table 4). Interestingly, while 2F5 resistance was found to be associated with the absence of DKW motif in gp41 in most of the Envs, this motif was found to be present in IVC3-3-9F1, IVC3-5-25F2, and all the Envs obtained from IVC-11 and conferred resistance as shown in Additional file 2: Table S1. Our data indicate that residues outside MPER domain possibly modulated 2F5 sensitivity despite the presence of a minimum DKW motif in MPER for 2F5 sensitivity. The ability of 4E10 to neutralize all the env clones was in agreement with the presence of WFXI motif in gp 41; however 4 Envs (4-2_NEM.J46b, 4-5_NEM.J5, 5-3_NEM.J4 and 5-3_NEM. J9) despite having WFXI motif (a minimum 4E10 recognition motif), they were found to be moderately resistant to $4 \mathrm{E} 10$ up to a concentration of $6.66 \mu \mathrm{g} / \mathrm{ml}$ (Additional file 1: Figure S1 and Additional file 2: Table S1).

\section{Envs from one patient (NARI-IVC2) were moderately sensitive to $\lg \mathrm{G} 1 \mathrm{~b} 12$ but were resistant to contemporaneous plasma antibodies}

In contrast all others, Envs amplified from a patient (NARI-IVC2) showed reasonable sensitivity to b12 MAb that targets CD4bs in Env. As shown in Figure 4, these Envs were found to provide a $50 \%$ reduction in infection in TZM-bl cells at concentrations ranging from 0.2 to $2.23 \mu \mathrm{g} / \mathrm{ml}$. The extent of b12 sensitivities of Envs obtained from this particular patient were found to be much higher than the two b12-sensitive Indian clade $C$ Envs reported by Kulkarni et al [27]. The degree of b12 sensitivity of IVC Envs, however, did not correlate with 


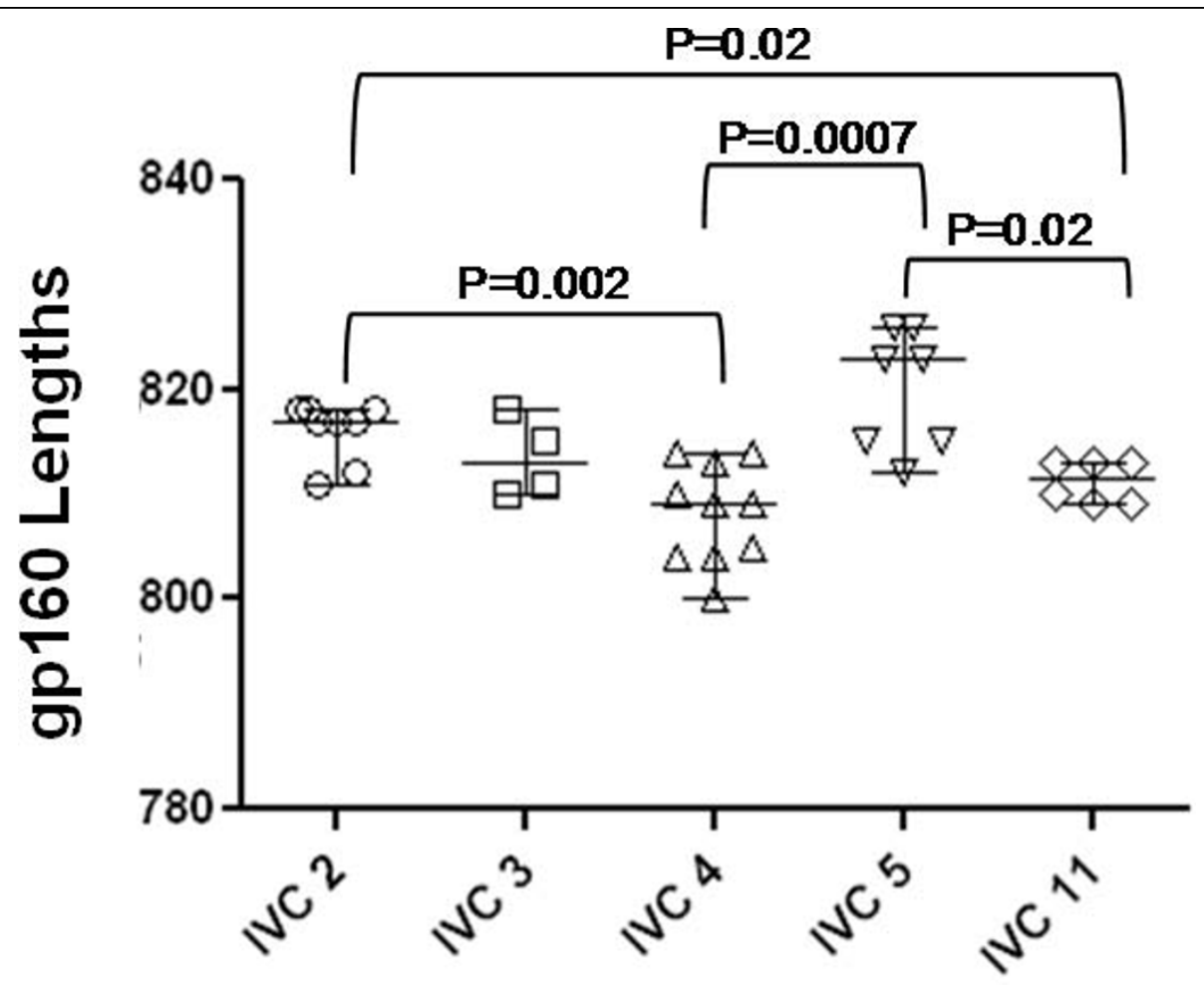

Figure 3 Variations in total gp160 lengths of Env clones obtained at different times in each patient during the course of infection Each bar represents median gp160 residues. Note that significant differences in median gp160 lengths of Envs between IVC 2 and 4, IVC 2 and 11 IVC 4 and 5 and IVC 5 and 11.

their sensitivity to sCD4 and contemporaneous plasma antibodies. Thus, Envs 2-3.J18, 2-5.J3 and 2-5.J11 which showed the highest neutralization sensitivity $\left(\mathrm{IC}_{50}\right.$ of 0.5 , 0.29 and $0.21 \mu \mathrm{g} / \mathrm{ml}$ respectively) to b12 required more sCD4 for 50\% neutralization and except for 2-3.J18 showed neutralization resistance to contemporaneous plasma antibodies (Tables 3 and 4). Our data indicated that escape from contemporaneous NAbs in turn mounted structural constraints in Env specifically on CD4 binding site. This feature therefore possibly contributed in reduced sensitivity of NAb resistant IVC2 envelopes to $\mathrm{sCD} 4$, although all envelopes in this patient surprisingly retained b12 sensitivity.

Sensitivity of Envs to contemporaneous autologous NAbs correlated positively with increased sensitivity to sCD4 and inversely with anti-CD4 antibody

To assess whether the increased sensitivity of patient envelopes to autologous NAbs could be due to greater flexibilities of gp120 interactions with CD4, we next compared the sensitivities of patient Envs to autologous plasmas, sCD4 and an anti-CD4 monoclonal antibody (SIM.2) (hybridoma supernatant) that blocks gp120-CD4 binding. Interestingly, Envs that were resistant to contemporaneous plasmas were less sensitive to sCD4 and required less anti-CD4 antibody (SIM.2) for 50\% inhibition. Thus, as shown in Figure 5, a positive association was seen between Env sensitivity to contemporaneous autologous plasma and an increased sensitivity to SCD4 and inverse correlation between Env sensitivity to autologous NAb anti-CD4 antibody, suggesting that Envs with increased sensitivities to $\mathrm{SCD} 4$ exhibited greater exposure of epitopes than are targeted by autologous antibodies. The reduced sensitivity of Envs to SIM.2 suggests that Envs with more exposed epitopes for sCD4 require more anti-CD4 antibody for optimum inhibition to entry. Overall, the sensitivities of Envs to sCD4 varied and inversely correlated with their inhibition by SIM.2.

Increased sensitivity of patient Envs to contemporaneous $\mathrm{NAb}$ and $\mathrm{sCD} 4$ correlated with reduced CD4 dependence We next investigated if Envs with increased sensitivity to autologous antibodies and sCD4 exhibited greater binding to cell surface CD4. Thus, HeLa cells expressing low CD4 but high CCR5 (RC49 cell line) were infected with Env-pseudotyped viruses and the degree of infection was obtained by measuring the intracellular p24. As shown in Figure 6, Envs with increased sensitivity to autologous NAbs (such as 2-3.J18, 3-3.J9, 4.J2, 4-2.J45, 5-4.J22 and 
Table 3 Neutralization sensitivity of patient envelopes to autologous plasma antibodies

\begin{tabular}{|c|c|c|c|}
\hline $\begin{array}{l}\text { Env } \\
\text { clones }\end{array}$ & $\begin{array}{l}\text { Baseline } \\
\text { plasma }\end{array}$ & $\begin{array}{l}\text { Plasma First visit } \\
\text { (F1) }\end{array}$ & $\begin{array}{l}\text { Plasma Second visit } \\
\text { (F2) }\end{array}$ \\
\hline 2.18 & 601 & 228 & $<20$ \\
\hline 2.J9 & 522 & 240 & $<20$ \\
\hline $2-3 . J 4$ & 350 & $<20$ & $<20$ \\
\hline $2-3 . J 7$ & 374 & $<50$ & $<20$ \\
\hline $2-3.517$ & 300 & $<20$ & $<20$ \\
\hline $2-3 . J 18$ & $<20$ & 540 & 652 \\
\hline $2-5 . J 3$ & $<50$ & $<20$ & $<20$ \\
\hline $2-5.511$ & 50 & $<20$ & $<20$ \\
\hline 3.116 & 195 & 696 & 2389 \\
\hline $3-3.59$ & 349 & 554 & 1053 \\
\hline $3-5 . J 25$ & $<20$ & $<20$ & 184 \\
\hline $3-5 . J 38$ & $<20$ & $<20$ & 72 \\
\hline $4 . J 2$ & 421 & 2671 & 3848 \\
\hline 4.J22 & 87 & 811 & 1172 \\
\hline 4.J27 & 74 & 773 & 871 \\
\hline $4-2 . J 41$ & 103 & 98 & 406 \\
\hline $4-2 . J 45$ & 3375 & 6287 & 8307 \\
\hline $4-2 . J 42 b$ & 60 & $<20$ & 115 \\
\hline 4-2.J45b & 70 & $<50$ & 500 \\
\hline 4-2.J46b & $<50$ & $<50$ & 160 \\
\hline 4-2.J47b & 72 & $<50$ & 340 \\
\hline $4-5 . J 5$ & 64 & $<20$ & 244 \\
\hline $5 . J 41$ & $<20$ & 110 & 1934 \\
\hline $5-3 . J 2$ & $<20$ & $<20$ & 1845 \\
\hline 5-3.J4 & $<20$ & $<20$ & 1067 \\
\hline 5-3.J5 & $<20$ & $<20$ & 1161 \\
\hline 5-3.J9 & $<20$ & $<20$ & 1104 \\
\hline $5-4 . J 16$ & $<20$ & $<20$ & $<50$ \\
\hline 5-4.J18 & $<20$ & $<20$ & $<50$ \\
\hline $5-4 . J 22$ & $<20$ & $<50$ & 223 \\
\hline $5-4 . J 49$ & $<20$ & $<50$ & 180 \\
\hline 11.J25 & 66 & 2158 & 2830 \\
\hline 11.J28 & 76 & 2008 & 2310 \\
\hline $11-3 . J 3$ & $<20$ & $<50$ & 1193 \\
\hline $11-3.59$ & $<20$ & $<20$ & 148 \\
\hline $11-3 . J 16$ & $<20$ & $<20$ & 201 \\
\hline 11-5.J12 & $<20$ & $<20$ & $<50$ \\
\hline
\end{tabular}

Values are reciprocal titer of patient plasma resulting 50\% reduction in relative luminescence unit (RLU) as an indicator of neutralization sensitivity in TZM-bl cells following infection with pseudoviruses with $200 T C I D_{50}$. The $I_{50}$ values are average of two independent assays wherein each assay was done in duplicates.

5-4.J49) showed reduced CD4 dependence. However, this phenomenon was found to be independent of the patients and the follow up times examined here (Additional file 3: Figure S2). As expected, we found that
Table 4 Neutralization sensitivity to monoclonal antibodies, sCD4 and anti-CD4

\begin{tabular}{|c|c|c|c|c|c|c|c|c|}
\hline$n v \mathrm{C}$ & b6 & b12 & $2 \mathrm{G} 12$ & $17 \mathrm{~b}$ & $2 \mathrm{~F} 5$ & 4E10 & sCD4 & SIM \\
\hline 2.J8 & $>6.66$ & 2.23 & .66 & $>6.66$ & $>6.66$ & 0.34 & 3.66 & 120 \\
\hline 2.J9 & 66 & 16 & .66 & $>6.66$ & 6.66 & .38 & 327 & 4 \\
\hline $2-3.14$ & $>6.66$ & .97 & $>6.66$ & $>6.66$ & 6 & 36 & 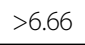 & 260 \\
\hline $2-3 . J 7$ & 56 & 2.19 & 6 & 66 & 56 & 5.85 & $>6.66$ & \\
\hline 2-3.J17 & $>6.66$ & 2.04 & 6.66 & $>6.66$ & $>6.66$ & 4.85 & $>6.66$ & 106 \\
\hline $2-3 . J 18$ & $>6.66$ & 0.5 & $>6.66$ & 5.1 & $>6.66$ & 4.5 & $>6.66$ & 37 \\
\hline $2-5.13$ & $>6.66$ & 0.29 & $>6.66$ & $>6.66$ & $>6.66$ & 2.69 & $>6.66$ & 20 \\
\hline $2-$ & $>6.66$ & 0.21 & $>6.66$ & $>6.66$ & $>6.66$ & 0.32 & 6.05 & 152 \\
\hline 3.J16 & $>6.66$ & $>6.66$ & 4.20 & $>6.66$ & $>c$ & 0.23 & 0 & \\
\hline 3-3.J9 & 6.66 & $>6.66$ & 0 & 2.9 & $>$ & 0.3 & 0.1 & \\
\hline $3-5 . J 25$ & $>6.66$ & $>6.66$ & 4.85 & $>6.66$ & $>6.66$ & 0 & 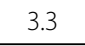 & 106 \\
\hline $3-5 . J 38$ & $>6.66$ & $>6.66$ & 4.30 & $>6.66$ & $>6.66$ & 2.22 & $>6.66$ & 79 \\
\hline 4.J2 & $>6.66$ & $>6.66$ & $>6.66$ & $>6.66$ & $>6.66$ & 0.28 & 0.5 & 10 \\
\hline 4.J22 & 5.66 & $>6.66$ & 6 & $>6.66$ & $>$ & 4 & $>$ & 138 \\
\hline 4.J27 & 66 & $>6.66$ & 6 & $>6.66$ & $>$ & 5.28 & $>$ & \\
\hline 4 & $>6.66$ & $>6.66$ & 6 & 66 & $>$ & 2 & 2.28 & \\
\hline $4-2$ & $>6.66$ & $>6.66$ & 6 & $>6.66$ & $>$ & 3.94 & 2.53 & 50 \\
\hline $4-2 . J 42 b$ & $>6.66$ & $>6.66$ & $>6.66$ & $>6.66$ & $>6.66$ & 5 & $>6$ & 2. \\
\hline $4-2 . J 45 b$ & $>6.66$ & $>6.66$ & $>6.66$ & $>6.66$ & $>6.66$ & 6.2 & $>6.66$ & 2 \\
\hline 4-2.J46b & $>6.66$ & $>6.66$ & $>6.66$ & $>6.66$ & $>6.66$ & $>6.66$ & $>6$. & 240 \\
\hline 4-2.J47b & $>6.66$ & $>6.66$ & $>6.66$ & $>6.66$ & $>6.66$ & 65 & 6 & 212 \\
\hline 4-5.J5 & 5 & 66 & 6 & 66 & 56 & $>6.66$ & $>$ & \\
\hline 5.J & $>6.66$ & $>6.66$ & $>6.66$ & 66 & $>6$ & 0.29 & 0 & 1114 \\
\hline $5-3 . J 2$ & $>6.66$ & $>6.66$ & $>6.66$ & $>6.66$ & $>6.66$ & 5.6 & $>6.66$ & 119 \\
\hline 5-3.J4 & $>6.66$ & $>6.66$ & $>6.66$ & $>6.66$ & $>6.66$ & $>6.66$ & $>6.66$ & 1 \\
\hline 3.15 & 5.9 & $>6.66$ & $>6.66$ & $>6.66$ & $>6.66$ & 5.66 & $>6$. & 2 \\
\hline 5-3.J9 & 566 & $>6.66$ & 5 & $>6.66$ & $>$ & $>6.66$ & $>6$ & \\
\hline 5 & $>6.66$ & $>6.66$ & $>$ & $>6.66$ & $>$ & 2.32 & 2.94 & 320 \\
\hline 5 & $>6.66$ & $>6.66$ & $>6.66$ & $>6.66$ & $>6.66$ & 2.52 & $>6$ & 1 \\
\hline 5-4.J22 & 2.5 & $>6.66$ & $>6.66$ & $>6.66$ & $>6.66$ & 0.24 & 0.23 & 44 \\
\hline $5-4 . J 49$ & 5.9 & $>6.66$ & $>6.66$ & $>6.66$ & $>6.66$ & 0.52 & 0.53 & 121 \\
\hline $11 . J 25$ & $>6.66$ & $>6.66$ & $>6.66$ & $>6.66$ & $>6.66$ & 0.34 & 3 & 99 \\
\hline 11.J28 & 66 & $>6.66$ & 6 & $>6.66$ & $>$ & 0.32 & 2.4 & 88 \\
\hline 1 & 66 & $>6.66$ & 6 & $>6.66$ & 56 & 54 & $>6.66$ & 548 \\
\hline $11-3 . J 9$ & $>6.66$ & $>6.66$ & 6.66 & $>6.66$ & $>6.66$ & 3.35 & $>6.66$ & 5 \\
\hline $11-3 . J 16$ & $>6.66$ & 6.05 & $>6.66$ & $>6.66$ & $>6.66$ & 3.25 & $>6.66$ & 585 \\
\hline $11-5 . J 12$ & $>6.66$ & $>6.66$ & $>6.66$ & $>6.66$ & $>6.66$ & 2.67 & $>6.66$ & 571 \\
\hline
\end{tabular}

Values are concentrations resulting $50 \%$ reduction in relative luminescence unit (RLU) as an indicator of neutralization sensitivity in TZM-bl cells following infection with pseudoviruses with $200 T \mathrm{CID}_{50}$. The $\mathrm{IC}_{50}$ values are average of two independent assays wherein each assay was done in duplicates. * The values corresponding to anti-CD4 SIM.2 is hybridoma fluid are reciprocal dilutions giving $50 \%$ reduction in relative luminescence unit (RLU).

increased sensitivity of Envs to autologous NAbs was correlated with reduced $\mathrm{CD} 4$ dependence $(\mathrm{P}<0.0155)$ and increased susceptibility to sCD4 $(\mathrm{P}<0.0001)$ (Figure 7). Collectively, our data showed an inverse 


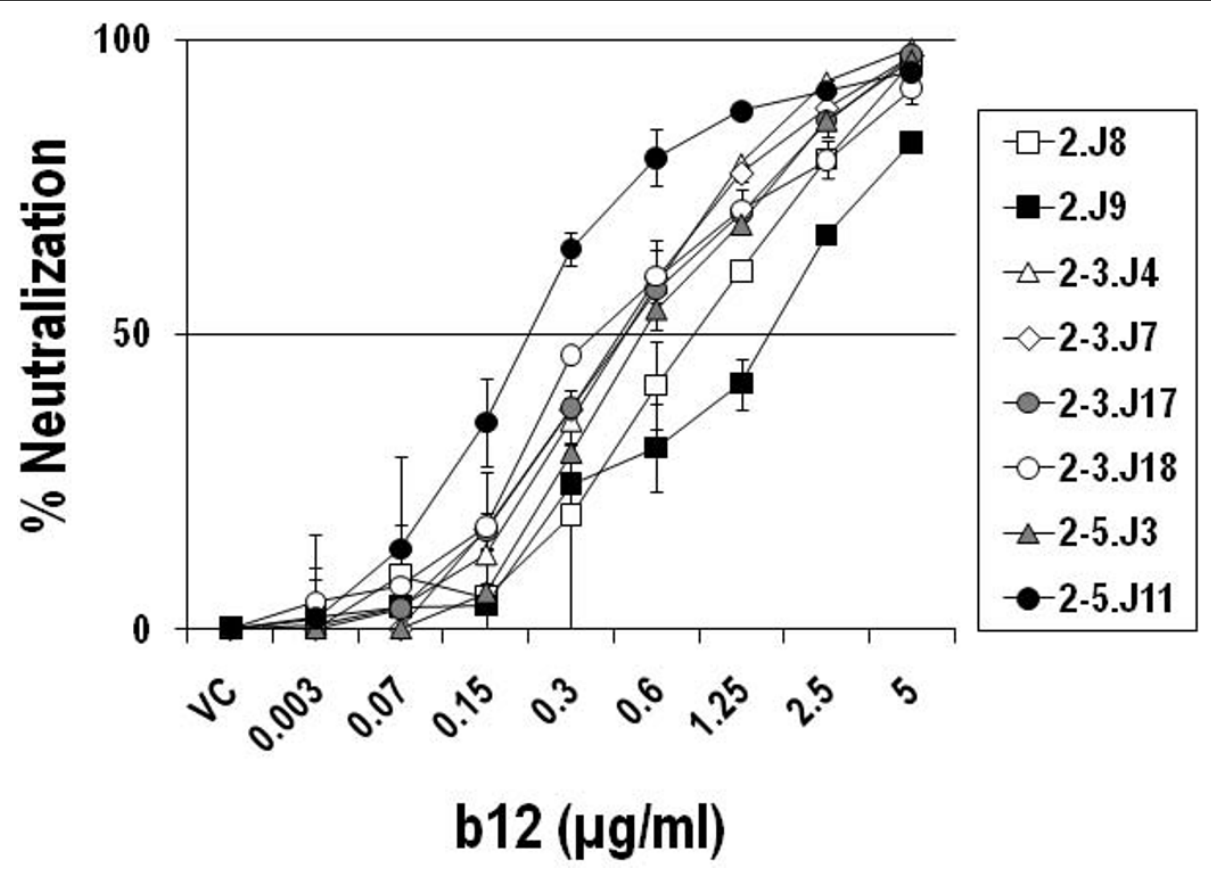

Figure 4 Sensitivity of Env clones amplified from IVC2 patients to IgG1b12 antibody. Env-pseudotyped viruses were incubated with IgG1b12 at indicated concentrations for 1 hour before TZM-bl cells were added as described in the Methods. The reduction of infectivity of TZM-bl cells was measured as a function of the degree of lgG1b12 mediated neutralization of these Envs.

association of autologous neutralization sensitivity of patient Envs with CD4 dependence.

\section{Discussion}

In contrast to the HIV-1 neutralization properties of African clade $\mathrm{C}$, there is only one report on the neutralization properties of HIV-1 clade C Env clones amplified from co-cultured PBMCs of acutely infected Indian patients [27]. One of the disadvantages in obtaining Env clones from co-culture is that it would potentially select for virus variants that become adapted for favorable replication in the absence of any immune pressure in vitro. This process would therefore fail to select viruses growing in vivo which are responsible for the pathogenesis in the natural course of infection. In the present study, we characterized for the first time the autologous $\mathrm{NAb}$ response in subtype $\mathrm{C} \mathrm{HIV-1}$ infected Indian patients using multiple molecular Env clones amplified without culture from each study subject. We found that while moderate $\mathrm{NAb}$ responses developed in three subjects (IVC 3, 4 and 11), no significant NAb response was detected at all three time points against contemporaneous autologous virus in the remaining two subjects (IVC 5 and IVC 11). In agreement with previous reports, as with both subtype $B$ and African subtype $C$ Envs, we found that in four patients (IVC3, 4, 5 and 11), Envs obtained at baseline and earlier time points were neutralized by plasma antibodies obtained at later time points, indicating repeated cycles of escape [45,52]. Of potential interest, Env clones obtained at all time points from IVC2 patient were moderately sensitive to IgG1b12, whereas Env clones from the remaining subjects were resistant to this MAb. Surprisingly NAb response in this patient waned over the period of time as plasma from later time points failed to neutralize many contemporaneous as well as earlier envelopes. Intriguingly, no correlation was observed between b12 sensitivity and SCD4 sensitivity as the b12 epitope overlaps CD4 binding site. One plausible explanation for this observation could be that this patient did not develop b12 like antibodies and possibly the absence of selective pressure on the b12 binding site caused the high sensitivity of these envelopes from IVC-2 towards b12. It was also possible that due to lack of co- evolution of b12 and other CD4 binding sites in Env, we did not find any association between b12 and sCD4 sensitivities to Env clones obtained from this particular patient. These observations indicate the presence of compensatory amino acid residues in the IVC-2 Env clones positioned either in the CD4bs or in the proximity that favored enhanced neutralization by b12 MAb. It would be important to further investigate the Env sequence that modulated b12 sensitivity in this patient.

Although we found repeated cycles of escape from autologous NAbs in all the patients, one Env variant (42_NEM.J45) obtained from patient NARI-IVC4 at the 


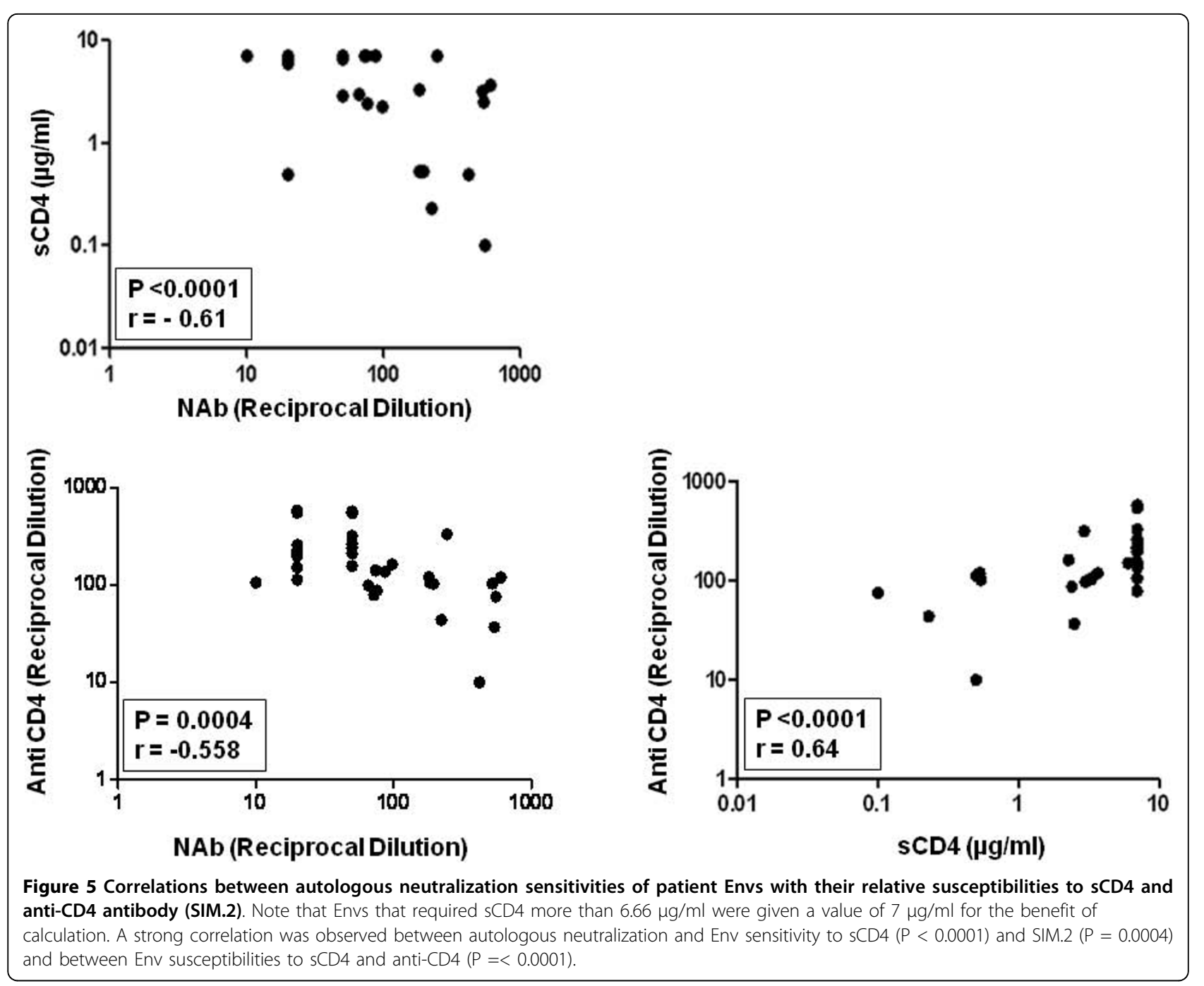

first follow up retained unusually high sensitivity to contemporaneous and earlier and follow-up plasmas with a mean $\mathrm{ID}_{50}$ of greater than 1: 3000. The persistence of this sensitive Env against which high titer of NAb was developed for at least 6 months makes this envelope interesting; in particular retention of neutralizing epitopes under immense humoral immune pressure probably indicates that this envelope might be more fit in terms of CTL pressure or increased infectivity to compensate for increased sensitivity to NAbs as previously described by Moore et al [45,52]. When tested against common HIV-1 neutralizing MAbs, most Envs obtained at different time points from all the five participants were resistant to IgGb6, IgG1b12, 2G12 and 2F5 and sensitive to 4E10 only. Intriguingly, two Env variants each from subjects IVC4 and IVC5 despite containing the minimum WFXI motif in gp41 MPER domain for $4 \mathrm{E} 10$ recognition, were found to require $4 \mathrm{E} 10$ antibody in excess $(>6.66 \mu \mathrm{g} / \mathrm{ml})$ of that required to provide $50 \%$ neutralization compared to all other Envs. Nakamura et al [78] recently showed that while $\mathrm{F} 673 \mathrm{~N}$ and W680G confers 4E10 resistance of HIV-1 envelopes, W680R showed variable 4E10 resistance. In all cases, $\mathrm{IC}_{50}$ values were reported to be in the range of greater than $50-100 \mu \mathrm{g} / \mathrm{ml}$. In our study, we did not find any of these substitutions in these four Envs, suggesting that the relative resistance of these Envs over others tested here are probably due to changes outside the MPER. Nonetheless, these 4 Envs showed $30-40 \%$ sensitivity to $4 \mathrm{E} 10$ at a concentration of $6.66 \mu \mathrm{g} / \mathrm{ml}$, indicating these Envs required excess $4 \mathrm{E} 10$ for $50 \%$ neutralization but certainly not as much as that would require for W680G or F673N as shown by Nakamura et al [78]. One Env variant each from subjects IVC2 and IVC 3 obtained at first follow up visits that showed unusual sensitivity to $17 \mathrm{~b}$, indicating exposed CD4i epitopes. These two Env variants in contrast to the majority of the Env clones were also found to be efficient at infecting HeLa cells 


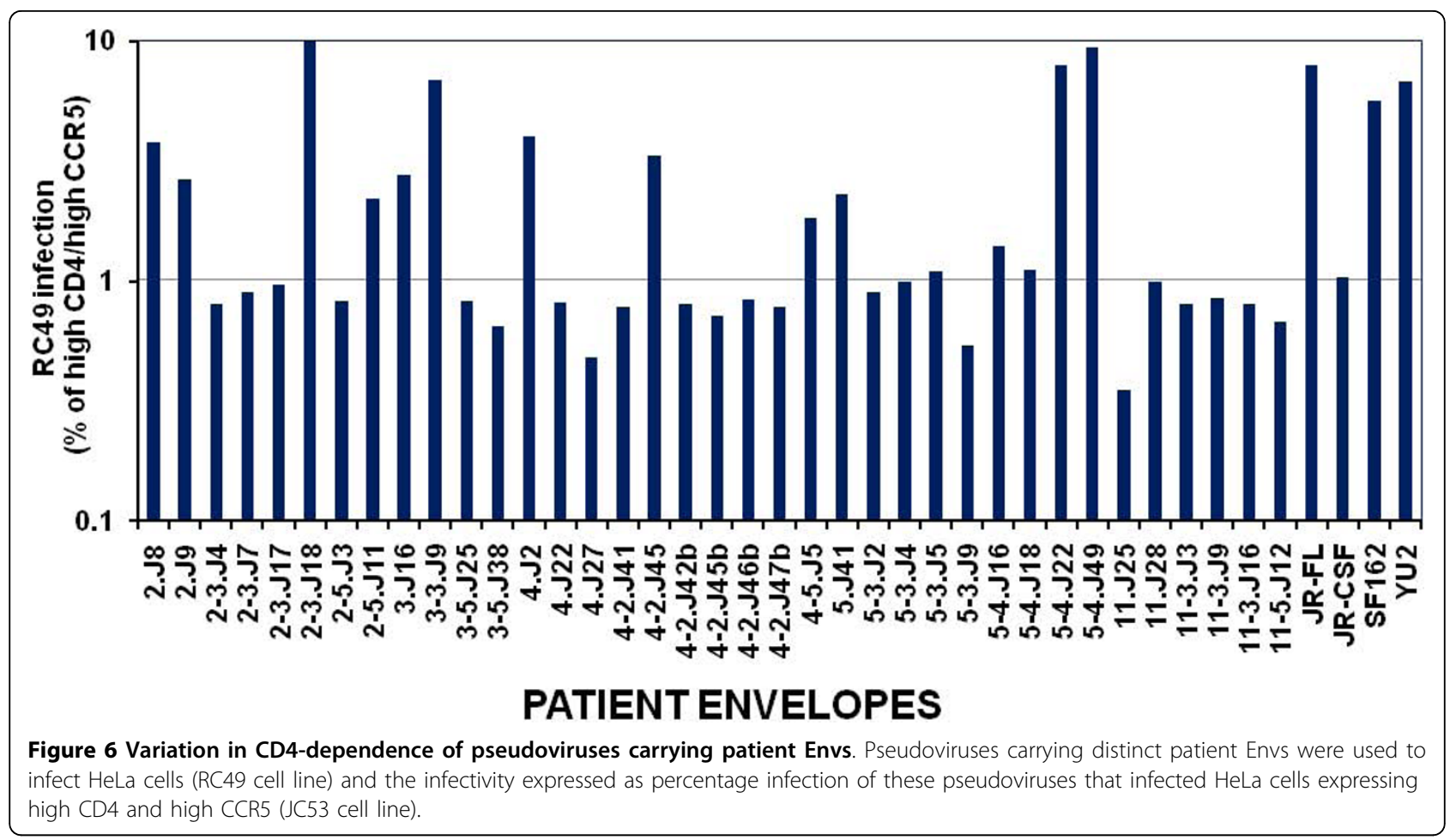

expressing low levels of CD4 thereby indicating the presence of exposed CD4i epitopes on Env that enabled them to productively infect HeLa cells expressing low CD4. Nonetheless, two Env variants (5.4.J22 and 5.4.J49) obtained from IVC 5 patient at 2 years showed increased infectivity to HeLa cells expressing low CD4 but were resistant to $17 \mathrm{~b}$, indicating that these Envs evolved to conceal their coreceptor binding region on gp120 without compromising low CD4 dependence in the same way that most circulating variants do.

How NAbs drive the Env evolution that impacts on CD4 affinity, tropism and sensitivity to NAbs is not very clear in early HIV-1 clade $C$ infection although two groups using HIV-1 clade B Envs showed association of R5 macrophage tropism with increased CD4 affinity consistent with increased resistance to anti-CD4

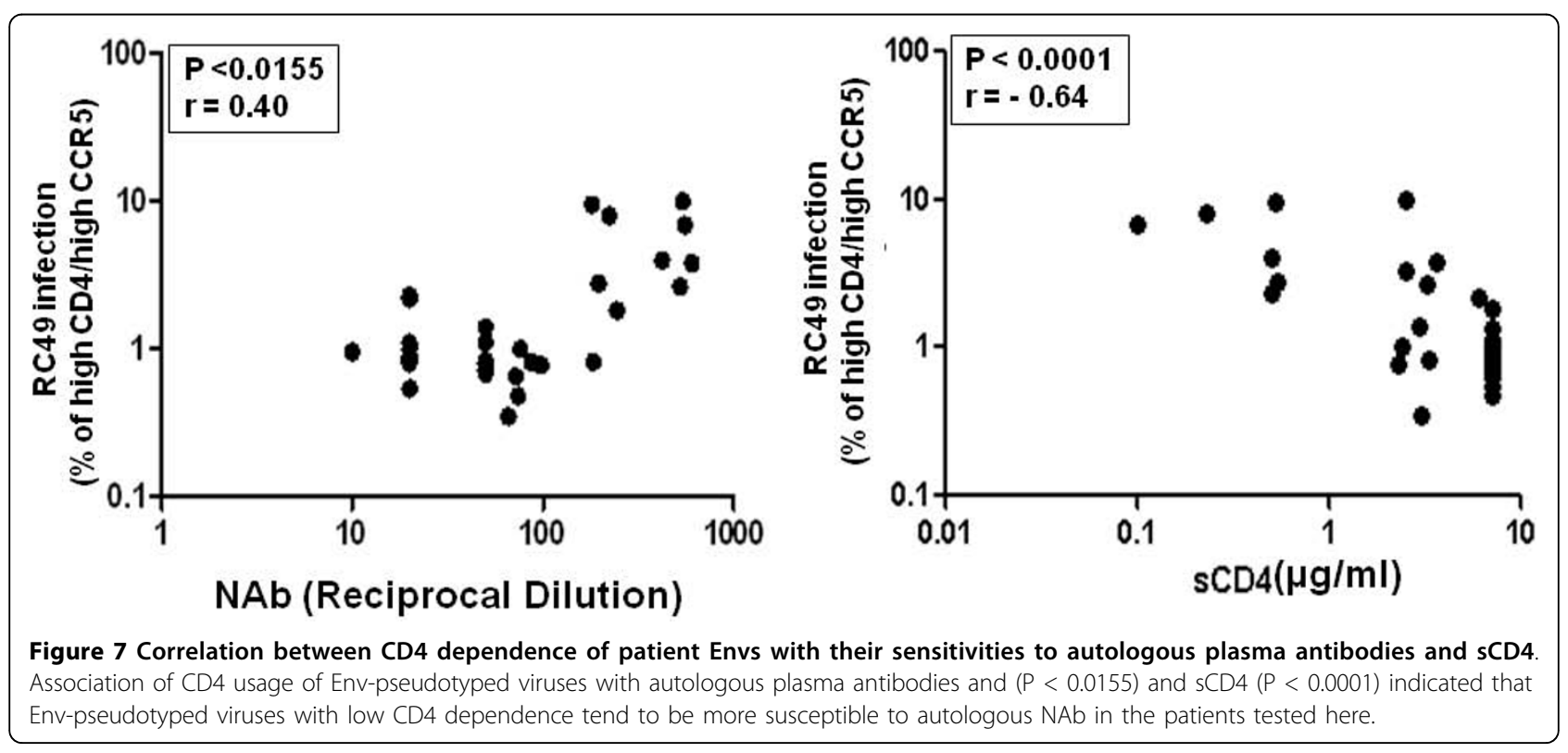


monoclonal antibodies $[79,80]$. Although in general, the majority of the Envs obtained from all the patients were moderately sensitive to sCD4, we found a few Envs (5. J41, 4-5.J5, 5-4.J16, 11.J25 and 11.J28) that showed autologous antibody resistance but were moderately sensitive to sCD4 indicating that these Envs evolved strategies in escaping autologous neutralization however they retained a very high affinity for the $\mathrm{CD} 4$ receptor. The CD4 binding site (CD4bs) on Env experiences most selective pressure as potent NAbs are directed to this domain as documented earlier $[15,49]$. Under this selective pressure exerted by humoral immunity, CD4bs is compelled to acquire changes in Env sequences to escape from NAbs that in turn would restrict Env binding efficiently to CD4 receptors [81]. In our study we found that all the Envs that were sensitive to autologous plasma antibodies were moderately susceptible to sCD4 indicating in this scenario, autologous NAbs were mostly directed towards the CD4 binding domain and escape from NAbs possibly had compromised Env binding with CD4. When tested for the extent of CD4 exposure of gp120, Envs that were sensitive to autologous antibodies as well as to $\mathrm{sCD} 4$ were found to require less cell surface CD4 for efficient entry, indicating an inverse correlation between Env sensitivity to autologous NAbs and CD4 dependence. The relationship between sensitivity of Envs to sCD4 and anti-CD4 antibodies with variable dependence to cell surface $\mathrm{CD} 4$ were described previously by different investigators. Gorry et al [82] showed that a neurotropic Env obtained from brain tissue with higher affinity to CD4 was found to be increasingly sensitive to CD4 mimetic, CD4-IgG2. Later, Dunfee et al [83] showed that Envs with N283 substitution could productively infect cells expressing low cell surface CD4 and show greater affinity to SCD4. Similar observations were found by Vermeire et al [81], where they showed that a NL4-3 variant that evolved to infect cells expressing low $\mathrm{CD} 4$ in presence of the small molecule CADA was found to be highly susceptible to heterologous sera and was concordant with increased sensitivity and resistance to $\mathrm{sCD} 4$ and anti-CD4 respectively. In addition, Peters et al $[79,84]$ demonstrated that patient-derived Envs that were able to exploit low CD4 on cell surface were proportionately resistant and sensitive to anti-CD4 antibody and $\mathrm{sCD} 4$ respectively.

In conclusion, in the present study, we have shown for the first time the neutralization properties of HIV-1 India clade $\mathrm{C}$ Env clones obtained from patients followed up with recent infection over time to their autologous antibodies during the natural course of infection and investigated their genetic relatedness with sensitivity to known broadly neutralizing monoclonal antibodies and degree of exposure to CD4 for efficient entry. While variations in autologous neutralization of viruses are expected, all available data on the mechanisms of resistance and sensitivity to neutralizing antibodies of geographically diversified $\mathrm{HIV}-1$ clade $\mathrm{C}$ that contributes to major global HIV-1 pandemic will help designing strategies fostering vaccine discovery.

\section{Methods}

\section{Patient details, PBMC and plasma samples}

All five recently infected study subjects acquired HIV-1 through heterosexual contacts and were ART naïve at the time of blood collection. The mean CD4 counts ranged from 328-606 cells per cubic millimeter $\left(\mathrm{mm}^{3}\right)$. Based on detuned ELISA results [85-87] and history of exposure within the last 6 to 8 months, these patients were selected as recently infected patients for further characterization. Plasmas used for HIV-1 envelope amplification and tested for antibody assays were obtained at baseline, 6 and 12 months respectively.

\section{Amplification and cloning of gp 160}

gp160 amplification from peripheral blood mononuclear cell (PBMC) DNA and from reverse-transcribed plasma viral RNA was carried out by nested PCR using 5'TAGAGCCCTGGAAGCATCCAGGAAG-3' as forward and 5'-TTGCTACTTGTGATTGCTCCATGT-3' as reverse primer in the first round and 5'-CACCGGCTTAGGCATCTCCTATGGCAGGAAGAA-3' as forward and 5'-TATCGGTACCAGTCTTGAGACGCTGCTCCTACTC-3' as reverse primer in the second round by using Platinum Taq proof reading polymerase (Invitrogen Inc.). Plasma viral RNA was purified by using a nucleic acid isolation kit as described by the manufacturer (Roche Inc.). cDNA from diluted viral RNA was prepared using Superscript III first strand synthesis kit (Invitrogen Inc.). gp160 was amplified by two rounds of nested PCR gp160 amplicons were purified and ligated into either pcDNA 3.1/V5-His-TOPO (Invitrogen Inc) or pSVIIIenv [84].

\section{DNA sequencing and phylogenetic analysis}

Sequence analysis was performed using cycle sequencing and big dye terminator methods by automated genetic analyzer (Applied Biosystems, Inc; Model 3730XL) as described earlier [88]. Nucleotide and deduced amino acid sequences were aligned using MEGA software and phylogenetic tree was constructed by the neighbor-joining method [88].

\section{Pseudovirion preparation and measurement of virus titer} Pseudotyped viruses carrying patient Envelope were produced by cotransfection of env ${ }^{+}$pSVIIIenv or env ${ }^{+}$ pcDNA 3.1/V5-His-TOPO with env-defective HIV-1 backbone vector (pSG3 $\Delta$ Env) $[44,89]$, into $293 \mathrm{~T}$ cells during $\log$ growth phase in 6 -well tissue culture trays 
(Corning Inc) using calcium phosphate (Promega Inc) following manufacturer's protocol. Cell supernatants carrying progeny pseudotyped viruses were harvested at 48 hours post-transfection, and stored at $-152^{\circ} \mathrm{C}$ until further usage. The infectivity assays were done in TZMbl cells in 96-well microtiter plate and infectivity titers determined by measuring the luciferase activity respectively as described elsewhere [90].

\section{Neutralization Assay}

Patient plasma samples were evaluated for NAb activity against Env pseudotyped viruses using a single round reporter assay in TZM-bl cells as described previously with few modification [90]. Briefly, $200 \mathrm{TCID}_{50}$ of pseudovirus was incubated with serial 3 fold dilutions of plasma sample in duplicates in a total volume of $150 \mu \mathrm{l}$ for $1 \mathrm{hr}$ at $37^{\circ} \mathrm{C}$ in 96 -well flat-bottom culture plates. Freshly trypsinized cells $(10,000$ cells in $100 \mu$ l of growth medium containing $25 \mathrm{ug} / \mathrm{ml}$ DEAE Dextran) were added to each well. One set of control wells received cells plus pseudovirus (virus control) and another set received cells only (background control). After 48 hours of incubation, luciferase activity was measured by using the Bright-Glo Luciferase Assay System (Promega Inc.). The $50 \%$ inhibitory dose $\left(\mathrm{ID}_{50}\right)$ was defined as either the plasma dilution or sample concentration (in the case of SCD4 and MAbs) that caused a 50\% reduction in relative luminescence units (RLU) compared to virus control wells after subtraction of background RLU.

\section{p24 antigen immunostaining}

Immunostaining of HeLa cells infected with pseudoviruses was carried out as described earlier [84]. p24 positive cells were regarded as foci of infection, and virus infectivity was estimated as focus-forming units (FFU) per milliliter.

\section{Nucleotide sequence accession numbers}

All env sequences have been submitted to GenBank (accession numbers: [GenBank:EU908214] to [GenBank: EU908221], [GenBank:EU908224] to [GenBank: EU908225], and [GenBank:GU945306] to [GenBank: GU945333]).

\section{Statistical analyses}

Correlations between NAb response and magnitude of envelope binding to sCD4, RC49 cells and anti-CD4 antibody (SIM.2) were assessed by calculating Spearman's non-parametric 2-tailed correlation co-efficient with 95\% confidence level using GraphPad Prism software. The percent infectivity of Env clones in HeLa cells expressing low CD4 (RC49) were plotted and compared by MannWhitney and two-way ANNOVA tests using GraphPad Prism software. Correlations were considered significant with $\mathrm{P}$ values less than 0.05 . To avoid digression of correlation, one Env clone (4.2J45) was not included during assessing the correlation between Env sensitivity to NAb and SCD4 (Figure 5) and between NAb and HeLa cell (RC49) (Figure 6B) infection as the sensitivity of this Env clone to it autologous plasma was exceptionally higher $\left(\mathrm{ID}_{50}\right.$ greater than 6000; see Table 3 ).

\section{Additional material}

Additional file 1: Figure S1. Alignments of deduced amino acids of
Indian clade C patient envelopes obtained at different course of
infection. Nucleotide sequences were translated and aligned using Mega
4.1. The residues were started from Kpnl site in gp120 and did not
include signal peptide. While dashes denote sequence identity in Env,
dots indicate gaps. Letters in lowercase in the consensus sequence
indicate residues under represented at that position in Envs obtained
from all the patients. Residues that differed significantly at a particular
position were denoted as X in the consensus sequence. Potential N-
linked glycosylation sites were underscored and highlighted.
Additional file 2: Table S1. 2 F5 and 4 E10 minimum motifs in MPER
domain in patient Envs and their corresponding sensitivities to 2 F5 and
4E10 monoclonal antibodies.
Additional file 3: Figure S2. Variations in CD4 dependence of patient
Envs obtained at different time points in each patient. Note that the bar
represents the median percentage infectivity of pseudoviruses to RC49
cells expressing low CD receptors.

\section{Abbreviations}

Env: (envelope); NAb: (neutralizing antibody); sCD4: (soluble CD4); MAb: (monoclonal antibody)

\section{Acknowledgements}

This study was supported primarily by a research grant from the Department of Biotechnology, Government of India (BT/PR7829/MED/14/ $1133 / 2006)$ to JB and in part by the Comprehensive Antibody-Vaccine Immune Monitoring Consortium through the Collaboration for AIDS Vaccine Discovery, as funded by the Bill \& Melinda Gates Foundation, and a component of the Global HIV Vaccine Enterprise (\#38619). We thank Dr Paul Clapham, University of Massachusetts Medical School, Worcester, USA for providing GHOST cell lines, JRCSF, JRFL, YU2 and SF162 Env clones and pSVIIlenv plasmid; and Dr David Kabat, University of Portland, Oregon, USA for providing engineered HeLa cell lines. We are grateful to Dr David Montefiori for helpful advice on neutralization assay and critical reading of the manuscript. We thank Dr James Robinson, University of Tulane for 17b MAb, Dr Dennis Burton, Scripps Research Institute, La Jolla,California for b6 MAb and NIH AIDS Research Reagent and Reference Program for making available many reagents used in this study. RR is supported by a Junior Research Fellowship from the Indian Council of Medical Research, Govt of India. We thank Director, NARI for support.

\section{Authors' contributions}

JB conceptualized and planned the study; RR carried out molecular cloning, neutralization assays and majority of the experiments; MT recruited patients with recent infections, did detuned ELISA and provided essential patient information including CD4 counts; RR and JB analyzed sequence analyses; JB wrote the manuscript with the help of RR and MT. All the authors have read and approved the final manuscript.

\section{Competing interests}

The authors declare that they have no competing interests.

Received: 31 May 2010 Accepted: 22 September 2010

Published: 22 September 2010 


\section{References}

1. Haynes BF, Montefiori DC: Aiming to induce broadly reactive neutralizing antibody responses with HIV-1 vaccine candidates. Expert Rev Vaccines 2006, 5:347-363.

2. Hu SL, Stamatatos L: Prospects of HIV Env modification as an approach to HIV vaccine design. Curr HIV Res 2007, 5:507-513.

3. Phogat S, Wyatt R: Rational modifications of HIV-1 envelope glycoproteins for immunogen design. Curr Pharm Des 2007, 13:213-227.

4. Burton DR, Desrosiers RC, Doms RW, Koff WC, Kwong PD, Moore JP Nabel GJ, Sodroski J, Wilson IA, Wyatt RT: HIV vaccine design and the neutralizing antibody problem. Nat Immunol 2004, 5:233-236.

5. Karlsson Hedestam GB, Fouchier RA, Phogat S, Burton DR, Sodroski J, Wyatt RT: The challenges of eliciting neutralizing antibodies to HIV-1 and to influenza virus. Nat Rev Microbiol 2008, 6:143-155.

6. Zhou T, Xu L, Dey B, Hessell AJ, Van Ryk D, Xiang SH, Yang X, Zhang MY, Zwick MB, Arthos J, Burton DR, Dimitrov DS, Sodroski J, Wyatt R, Nabel GJ, Kwong PD: Structural definition of a conserved neutralization epitope on HIV-1 gp120. Nature 2007, 445:732-737.

7. Braibant M, Brunet S, Costagliola D, Rouzioux C, Agut $H$, Katinger $H$, Autran B, Barin F: Antibodies to conserved epitopes of the HIV-1 envelope in sera from long-term non-progressors: prevalence and association with neutralizing activity. Aids 2006, 20:1923-1930.

8. Donners H, Willems B, Beirnaert E, Colebunders R, Davis D, van der Groen G: Cross-neutralizing antibodies against primary isolates in African women infected with HIV-1. Aids 2002, 16:501-503.

9. Gray ES, Moore PL, Choge IA, Decker JM, Bibollet-Ruche F, Li H, Leseka N, Treurnicht F, Mlisana K, Shaw GM, Karim SS, Williamson C, Morris L, CAPRISA 002 Study Team: Neutralizing antibody responses in acute human immunodeficiency virus type 1 subtype C infection. J Virol 2007. 81:6187-6196

10. Li B, Decker JM, Johnson RW, Bibollet-Ruche F, Wei X, Mulenga J, Allen S, Hunter E, Hahn BH, Shaw GM, Blackwell JL, Derdeyn CA: Evidence for potent autologous neutralizing antibody titers and compact envelopes in early infection with subtype $C$ human immunodeficiency virus type 1 . $J$ Virol 2006, 80:5211-5218.

11. Moog C, Fleury HJ, Pellegrin I, Kirn A, Aubertin AM: Autologous and heterologous neutralizing antibody responses following initial seroconversion in human immunodeficiency virus type 1-infected individuals. J Virol 1997, 71:3734-3741.

12. Pilgrim AK, Pantaleo G, Cohen OJ, Fink LM, Zhou JY, Zhou JT, Bolognesi DP, Fauci AS, Montefiori DC: Neutralizing antibody responses to human immunodeficiency virus type 1 in primary infection and long-termnonprogressive infection. J Infect Dis 1997, 176:924-932.

13. Richman DD, Wrin T, Little SJ, Petropoulos CJ: Rapid evolution of the neutralizing antibody response to HIV type 1 infection. Proc Natl Acad SC USA 2003, 100:4144-4149.

14. Kraft Z, Strouss K, Sutton WF, Cleveland B, Tso FY, Polacino P, Overbaugh J, Hu SL, Stamatatos L: Characterization of neutralizing antibody responses elicited by clade $A$ envelope immunogens derived from early transmitted viruses. J Virol 2008, 82:5912-5921.

15. Li Y, Migueles SA, Welcher B, Svehla K, Phogat A, Louder MK, Wu X, Shaw GM, Connors M, Wyatt RT, Mascola JR: Broad HIV-1 neutralization mediated by CD4-binding site antibodies. Nat Med 2007, 13:1032-1034

16. Wyatt $R$, Sodroski J: The HIV-1 envelope glycoproteins: fusogens, antigens, and immunogens. Science 1998, 280:1884-1888.

17. Parren PW, Mondor I, Naniche D, Ditzel HJ, Klasse PJ, Burton DR, Sattentau QJ: Neutralization of human immunodeficiency virus type 1 by antibody to gp120 is determined primarily by occupancy of sites on the virion irrespective of epitope specificity. J Virol 1998, 72:3512-3519.

18. Ugolini S, Mondor I, Parren PW, Burton DR, Tilley SA, Klasse PJ, Sattentau QJ: Inhibition of virus attachment to CD4+ target cells is a major mechanism of T cell line-adapted HIV-1 neutralization. J Exp Med 1997, 186:1287-1298

19. Labrijn AF, Poignard P, Raja A, Zwick MB, Delgado K, Franti M, Binley J, Vivona V, Grundner C, Huang CC, Venturi M, Petropoulos CJ, Wrin T, Dimitrov DS, Robinson J, Kwong PD, Wyatt RT, Sodroski J, Burton DR: Access of antibody molecules to the conserved coreceptor binding site on glycoprotein gp120 is sterically restricted on primary human immunodeficiency virus type 1. J Virol 2003, 77:10557-10565.

20. Deeks SG, Schweighardt B, Wrin T, Galovich J, Hoh R, Sinclair E, Hunt P, McCune JM, Martin JN, Petropoulos CJ, Hecht FM: Neutralizing antibody responses against autologous and heterologous viruses in acute versus chronic human immunodeficiency virus (HIV) infection: evidence for a constraint on the ability of HIV to completely evade neutralizing antibody responses. J Virol 2006, 80:6155-6164.

21. Doria-Rose NA, Klein RM, Manion MM, O'Dell S, Phogat A, Chakrabarti B, Hallahan CW, Migueles SA, Wrammert J, Ahmed R, Nason M, Wyatt RT, Mascola JR, Connors M: Frequency and phenotype of human immunodeficiency virus envelope-specific $B$ cells from patients with broadly cross-neutralizing antibodies. J Virol 2009, 83:188-199.

22. Binley JM, Lybarger EA, Crooks ET, Seaman MS, Gray E, Davis KL, Decker JM, Wycuff D, Harris L, Hawkins N, Wood B, Nathe C, Richman D, Tomaras GD, Bibollet-Ruche F, Robinson JE, Morris L, Shaw GM, Montefiori DC, Mascola JR: Profiling the specificity of neutralizing antibodies in a large panel of plasmas from patients chronically infected with human immunodeficiency virus type 1 subtypes B and C. J Virol 2008, 82:11651-11668.

23. Simek MD, Rida W, Priddy FH, Pung P, Carrow E, Laufer DS, Lehrman JK, Boaz M, Tarragona-Fiol T, Miiro G, Birungi J, Pozniak A, McPhee DA, Manigart O, Karita E, Inwoley A, Jaoko W, Dehovitz J, Bekker LG, Pitisuttithum P, Paris R, Walker LM, Poignard P, Wrin T, Fast PE, Burton DR, Koff WC: Human immunodeficiency virus type 1 elite neutralizers: individuals with broad and potent neutralizing activity identified by using a high-throughput neutralization assay together with an analytical selection algorithm. J Virol 2009, 83:7337-7348.

24. Mascola JR, Montefiori DC: The role of antibodies in HIV vaccines. Annu Rev Immunol 2010, 28:413-444.

25. Burton DR, Pyati J, Koduri R, Sharp SJ, Thornton GB, Parren PW, Sawyer LS, Hendry RM, Dunlop N, Nara PL: Efficient neutralization of primary isolates of HIV- 1 by a recombinant human monoclonal antibody. Science 1994, 266:1024-1027

26. Binley JM, Wrin T, Korber B, Zwick MB, Wang M, Chappey C, Stiegler G, Kunert R, Zolla-Pazner S, Katinger H, Petropoulos CJ, Burton DR: Comprehensive cross-clade neutralization analysis of a panel of antihuman immunodeficiency virus type 1 monoclonal antibodies. J Virol 2004, 78:13232-13252.

27. Kulkarni SS, Lapedes A, Tang H, Gnanakaran S, Daniels MG, Zhang M, Bhattacharya T, Li M, Polonis VR, McCutchan FE, Morris L, Ellenberger D, Butera ST, Bollinger RC, Korber BT, Paranjape RS, Montefiori DC: Highly complex neutralization determinants on a monophyletic lineage of newly transmitted subtype C HIV-1 Env clones from India. Virology 2009, 385:505-520.

28. Trkola A, Purtscher M, Muster T, Ballaun C, Buchacher A, Sullivan N, Srinivasan K, Sodroski J, Moore JP, Katinger H: Human monoclonal antibody $2 \mathrm{G} 12$ defines a distinctive neutralization epitope on the gp120 glycoprotein of human immunodeficiency virus type 1. J Virol 1996, 70:1100-1108.

29. Calarese DA, Scanlan CN, Zwick MB, Deechongkit S, Mimura $Y$, Kunert $R$, Zhu P, Wormald MR, Stanfield RL, Roux KH, Kelly JW, Rudd PM, Dwek RA, Katinger $\mathrm{H}$, Burton DR, Wilson IA: Antibody domain exchange is an immunological solution to carbohydrate cluster recognition. Science 2003, 300:2065-2071

30. Trkola A, Pomales AB, Yuan $H$, Korber B, Maddon PJ, Allaway GP, Katinger $H_{\text {, }}$ Barbas CF, Burton DR, Ho DD, et al: Cross-clade neutralization of primary isolates of human immunodeficiency virus type 1 by human monoclonal antibodies and tetrameric CD4-lgG. J Virol 1995, 69:6609-6617.

31. Li M, Salazar-Gonzalez JF, Derdeyn CA, Morris L, Williamson C, Robinson JE, Decker JM, Li Y, Salazar MG, Polonis VR, Mlisana K, Karim SA, Hong K, Greene KM, Bilska M, Zhou J, Allen S, Chomba E, Mulenga J, Vwalika C, Gao F, Zhang M, Korber BT, Hunter E, Hahn BH, Montefiori DC: Genetic and neutralization properties of subtype $C$ human immunodeficiency virus type 1 molecular env clones from acute and early heterosexually acquired infections in Southern Africa. J Virol 2006, 80:11776-11790.

32. Decker JM, Bibollet-Ruche F, Wei X, Wang S, Levy DN, Wang W, Delaporte E, Peeters M, Derdeyn CA, Allen S, Hunter E, Saag MS, Hoxie JA, Hahn BH, Kwong PD, Robinson JE, Shaw GM: Antigenic conservation and immunogenicity of the HIV coreceptor binding site. J Exp Med 2005 201:1407-1419.

33. Wyatt R, Kwong PD, Desjardins E, Sweet RW, Robinson J, Hendrickson WA, Sodroski JG: The antigenic structure of the HIV gp120 envelope glycoprotein. Nature 1998, 393:705-711. 
34. Thali M, Moore JP, Furman C, Charles M, Ho DD, Robinson J, Sodroski J: Characterization of conserved human immunodeficiency virus type 1 gp120 neutralization epitopes exposed upon gp120-CD4 binding. J Virol 1993, 67:3978-3988.

35. Xiang SH, Doka N, Choudhary RK, Sodroski J, Robinson JE: Characterization of CD4-induced epitopes on the HIV type $1 \mathrm{gp} 120$ envelope glycoprotein recognized by neutralizing human monoclonal antibodies. AIDS Res Hum Retroviruses 2002, 18:1207-1217.

36. Moulard M, Phogat SK, Shu Y, Labrijn AF, Xiao X, Binley JM, Zhang MY, Sidorov IA, Broder CC, Robinson J, Parren PW, Burton DR, Dimitrov DS: Broadly cross-reactive HIV-1-neutralizing human monoclonal Fab selected for binding to gp120-CD4-CCR5 complexes. Proc Natl Acad Sci USA 2002, 99:6913-6918.

37. Cardoso RM, Zwick MB, Stanfield RL, Kunert R, Binley JM, Katinger $\mathrm{H}_{\text {, }}$ Burton DR, Wilson IA: Broadly neutralizing anti-HIV antibody 4E10 recognizes a helical conformation of a highly conserved fusionassociated motif in gp41. Immunity 2005, 22:163-173.

38. Zwick MB, Labrijn AF, Wang M, Spenlehauer C, Saphire EO, Binley JM, Moore JP, Stiegler G, Katinger H, Burton DR, Parren PW: Broadly neutralizing antibodies targeted to the membrane-proximal external region of human immunodeficiency virus type 1 glycoprotein gp41. J Virol 2001, 75:10892-10905.

39. Muster T, Steindl F, Purtscher M, Trkola A, Klima A, Himmler G, Ruker F, Katinger $\mathrm{H}$ : A conserved neutralizing epitope on gp41 of human immunodeficiency virus type. J Virol 1993, 67:6642-6647.

40. Binley JM, Cayanan CS, Wiley C, Schulke N, Olson WC, Burton DR: Redoxtriggered infection by disulfide-shackled human immunodeficiency virus type 1 pseudovirions. J Virol 2003, 77:5678-5684.

41. Yuste E, Sanford HB, Carmody J, Bixby J, Little S, Zwick MB, Greenough T, Burton DR, Richman DD, Desrosiers RC, Johnson WE: Simian immunodeficiency virus engrafted with human immunodeficiency virus type 1 (HIV-1)-specific epitopes: replication, neutralization, and survey of HIV-1-positive plasma. J Virol 2006, 80:3030-3041.

42. Gray ES, Taylor N, Wycuff D, Moore PL, Tomaras GD, Wibmer CK, Puren A, DeCamp A, Gilbert PB, Wood B, Montefiori DC, Binley JM, Shaw GM, Haynes BF, Mascola JR, Morris L: Antibody specificities associated with neutralization breadth in plasma from human immunodeficiency virus type 1 subtype C-infected blood donors. J Virol 2009, 83:8925-8937.

43. Albert J, Abrahamsson B, Nagy K, Aurelius E, Gaines H, Nystrom G, Fenyo EM: Rapid development of isolate-specific neutralizing antibodies after primary HIV-1 infection and consequent emergence of virus variants which resist neutralization by autologous sera. Aids 1990, 4:107-112.

44. Wei X, Decker JM, Wang S, Hui H, Kappes JC, Wu X, Salazar-Gonzalez JF, Salazar MG, Kilby JM, Saag MS, Komarova NL, Nowak MA, Hahn BH, Kwong PD, Shaw GM: Antibody neutralization and escape by HIV-1. Nature 2003, 422:307-312.

45. Bunnik EM, Pisas $L$, van Nuenen AC, Schuitemaker H: Autologous neutralizing humoral immunity and evolution of the viral envelope in the course of subtype B human immunodeficiency virus type 1 infection. J Virol 2008, 82:7932-7941.

46. Moore PL, Gray ES, Choge IA, Ranchobe N, Mlisana K, Abdool Karim SS, Williamson C, Morris L: The C3-v4 region is a major target of autologous neutralizing antibodies in human immunodeficiency virus type 1 subtype C infection. J Virol 2008, 82:1860-1869.

47. Davis KL, Gray ES, Moore PL, Decker JM, Salomon A, Montefiori DC, Graham BS, Keefer MC, Pinter A, Morris L, Hahn BH, Shaw GM: High titer HIV-1 V3-specific antibodies with broad reactivity but low neutralizing potency in acute infection and following vaccination. Virology 2009, 387:414-26.

48. Salazar-Gonzalez JF, Salazar MG, Keele BF, Learn GH, Giorgi EE, Li H, Decker JM, Wang S, Baalwa J, Kraus MH, Parrish NF, Shaw KS, Guffey MB, Bar KJ, Davis KL, Ochsenbauer-Jambor C, Kappes JC, Saag MS, Cohen MS, Mulenga J, Derdeyn CA, Allen S, Hunter E, Markowitz M, Hraber P, Perelson AS, Bhattacharya T, Haynes BF, Korber BT, Hahn BH, Shaw GM: Genetic identity, biological phenotype, and evolutionary pathways of transmitted/founder viruses in acute and early HIV-1 infection. J Exp Med 2009, 206:1273-1289.

49. Rong R, Bibollet-Ruche F, Mulenga J, Allen S, Blackwell JL, Derdeyn CA: Role of V1V2 and other human immunodeficiency virus type 1 envelope domains in resistance to autologous neutralization during clade $C$ infection. J Virol 2007, 81:1350-1359.

50. Rong R, Gnanakaran S, Decker JM, Bibollet-Ruche F, Taylor J, Sfakianos JN, Mokili JL, Muldoon M, Mulenga J, Allen S, Hahn BH, Shaw GM, Blackwell JL, Korber BT, Hunter E, Derdeyn CA: Unique mutational patterns in the envelope alpha 2 amphipathic helix and acquisition of length in gp120 hypervariable domains are associated with resistance to autologous neutralization of subtype $C$ human immunodeficiency virus type 1 . J Virol 2007, 81:5658-5668.

51. Moore PL, Ranchobe N, Lambson BE, Gray ES, Cave E, Abrahams MR, Bandawe G, Mlisana K, Abdool Karim SS, Williamson C, Morris L: Limited neutralizing antibody specificities drive neutralization escape in early HIV-1 subtype C infection. PLoS Pathog 2009, 5:e1000598.

52. Rong R, Li B, Lynch RM, Haaland RE, Murphy MK, Mulenga J, Allen SA, Pinter A, Shaw GM, Hunter E, Robinson JE, Gnanakaran S, Derdeyn CA: Escape from autologous neutralizing antibodies in acute/early subtype C HIV-1 infection requires multiple pathways. PLoS Pathog 2009, 5: e1000594.

53. Bouma P, Leavitt M, Zhang PF, Sidorov IA, Dimitrov DS, Quinnan GV Jr: Multiple interactions across the surface of the gp120 core structure determine the global neutralization resistance phenotype of human immunodeficiency virus type 1. J Virol 2003, 77:8061-8071.

54. Carrillo A, Ratner $L$ : Cooperative effects of the human immunodeficiency virus type 1 envelope variable loops V1 and V3 in mediating infectivity for T cells. J Virol 1996, 70:1310-1316.

55. Cheng-Mayer C, Brown A, Harouse J, Luciw PA, Mayer AJ: Selection for neutralization resistance of the simian/human immunodeficiency virus SHIVSF33A variant in vivo by virtue of sequence changes in the extracellular envelope glycoprotein that modify N-linked glycosylation. J Virol 1999, 73:5294-5300.

56. Gram GJ, Hemming A, Bolmstedt A, Jansson B, Olofsson S, Akerblom L, Nielsen JO, Hansen JE: Identification of an N-linked glycan in the V1-loop of HIV-1 gp120 influencing neutralization by anti-V3 antibodies and soluble CD4. Arch Virol 1994, 139:253-261.

57. Koito A, Harrowe G, Levy JA, Cheng-Mayer C: Functional role of the V1/V2 region of human immunodeficiency virus type 1 envelope glycoprotein gp120 in infection of primary macrophages and soluble CD4 neutralization. J Virol 1994, 68:2253-2259.

58. Kolchinsky P, Kiprilov E, Bartley P, Rubinstein R, Sodroski J: Loss of a single $\mathrm{N}$-linked glycan allows CD4-independent human immunodeficiency virus type 1 infection by altering the position of the gp120 V1/V2 variable loops. J Virol 2001, 75:3435-3443.

59. Korber B, Gaschen B, Yusim K, Thakallapally R, Kesmir C, Detours V: Evolutionary and immunological implications of contemporary HIV-1 variation. Br Med Bull 2001, 58:19-42.

60. Morikita T, Maeda Y, Fujii S, Matsushita S, Obaru K, Takatsuki K: The V1/N2 region of human immunodeficiency virus type 1 modulates the sensitivity to neutralization by soluble CD4 and cellular tropism. AIDS Res Hum Retroviruses 1997, 13:1291-1299.

61. Pincus SH, Messer KG, Nara PL, Blattner WA, Colclough G, Reitz M: Temporal analysis of the antibody response to HIV envelope protein in HIV-infected laboratory workers. J Clin Invest 1994, 93:2505-2513.

62. Edwards TG, Hoffman TL, Baribaud F, Wyss S, LaBranche CC, Romano J, Adkinson J, Sharron M, Hoxie JA, Doms RW: Relationships between CD4 independence, neutralization sensitivity, and exposure of a CD4-induced epitope in a human immunodeficiency virus type 1 envelope protein. $J$ Virol 2001, 75:5230-5239.

63. Dumonceaux J, Goujon C, Joliot V, Briand P, Hazan U: Determination of essential amino acids involved in the CD4-independent tropism of the $\mathrm{X} 4$ human immunodeficiency virus type $1 \mathrm{m7NDK}$ isolate: role of potential $\mathrm{N}$ glycosylations in the C2 and V3 regions of gp120. J Virol 2001, 75:5425-5428.

64. Joliot V, Goujon C, Dumonceaux J, Renard A, Briand P, Hazan U: A human immunodeficiency virus Env inducible transcription system to examine consequences of gp120 expression. J Virol Methods 2001, 98:145-151.

65. Rossi F, Querido B, Nimmagadda M, Cocklin S, Navas-Martin S, MartinGarcia J: The V1-V3 region of a brain-derived HIV-1 envelope glycoprotein determines macrophage tropism, low CD4 dependence, increased fusogenicity and altered sensitivity to entry inhibitors. Retrovirology 2008, 5:89. 
66. Esparza J, Bhamarapravati N: Accelerating the development and future availability of HIV-1 vaccines: why, when, where, and how? Lancet 2000, 355:2061-2066.

67. Moore JP, Parren PW, Burton DR: Genetic subtypes, humoral immunity, and human immunodeficiency virus type 1 vaccine development. J Virol 2001, 75:5721-5729.

68. Osmanov S, Pattou C, Walker N, Schwardlander B, Esparza J: Estimated global distribution and regional spread of HIV-1 genetic subtypes in the year 2000. J Acquir Immune Defic Syndr 2002, 29:184-190.

69. Shankarappa R, Chatterjee R, Learn GH, Neogi D, Ding M, Roy P, Ghosh A, Kingsley L, Harrison L, Mullins II, Gupta P: Human immunodeficiency virus type 1 env sequences from Calcutta in eastern India: identification of features that distinguish subtype $C$ sequences in India from other subtype C sequences. J Virol 2001, 75:10479-10487, 75.

70. Peeters M: Recombinant HIV sequences: their role in the global epidemic. In HIV sequence compendium 2000 Theoretical Biology and Biophysics Group. Edited by: Kuiken FB, Hahn CB, Marx P, McCutchan F, Mellors J, Mullins J, Sodroski J, Wolinksy S, Korber B. Los Alamos National Laboratory, Los Alamos, N Mex; 2000:39-54.

71. Gray ES, Moore PL, Bibollet-Ruche F, Li H, Decker JM, Meyers T, Shaw GM, Morris L: 4E10-resistant variants in a human immunodeficiency virus type 1 subtype $C$-infected individual with an anti-membrane-proximal external region-neutralizing antibody response. J Virol 2008, 82:2367-2375.

72. Gray ES, Moore PL, Pantophlet RA, Morris L: N-linked glycan modifications in gp120 of human immunodeficiency virus type 1 subtype $C$ render partial sensitivity to $2 \mathrm{G} 12$ antibody neutralization. J Virol 2007, 81:10769-10776.

73. Agnihotri KD, Tripathy SP, Jere AP, Kale SM, Paranjape RS: Molecular analysis of gp41 sequences of HIV type 1 subtype $C$ from India. J Acquir Immune Defic Syndr 2006, 41:345-351.

74. Jere A, Tripathy S, Agnihotri K, Jadhav S, Paranjape R: Genetic analysis of Indian HIV-1 nef: subtyping, variability and implications. Microbes Infect 2004, 6:279-289.

75. Kurle S, Tripathy S, Jadhav S, Agnihotri K, Paranjape R: Full-length gag sequences of HIV type 1 subtype $C$ recent seroconverters from Pune, India. AIDS Res Hum Retroviruses 2004, 20:1113-1118.

76. Agnihorti K, Tripathy S, Jere A, Jadhav S, Kurle S, Paranjape R: gp120 sequences from HIV type 1 subtype $C$ early seroconverters in India. AIDS Res HumRetroviruses 2004, 20:889-894.

77. Khan IF, Vajpayee M, Prasad W, Seth P: Genetic diversity of HIV type 1 subtype $C$ env gene sequences from India. AIDS Res Hum Retroviruses 2007, 23:934-940.

78. Nakamura K, Gach JS, Jones L, Semrau K, Walter J, Bibollet-Ruche F, Decker JM, Heath L, Decker WD, Sinkala M, Kankasa C, Thea D, Mullins J, Kuhn L, Zwick MB, Aldrovand GM: 4E10-Resistant HIV-1 Isolated from Four Subjects with Rare Membrane-Proximal External Region Polymorphisms. Plos One 2010, 5(3):e9786.

79. Peters PJ, Duenas-Decamp MJ, Sullivan WM, Brown R, Ankghuambom C, Luzuriaga K, Robinson J, Burton DR, Bell J, Simmonds P, Ball J, Clapham PR: Variation in HIV-1 R5 macrophage-tropism correlates with sensitivity to reagents that block envelope: $\mathrm{CD} 4$ interactions but not with sensitivity to other entry inhibitors. Retrovirology 2008, 5:5.

80. Dunfee RL, Thomas ER, Gabuzda D: Enhanced macrophage tropism of HIV in brain and lymphoid tissues is associated with sensitivity to the broadly neutralizing CD4 binding site antibody b12. Retrovirology 2009, 6:69.

81. Vermeire K, Van Laethem K, Janssens W, Bell TW, Schols D: Human immunodeficiency virus type 1 escape from cyclotriazadisulfonamideinduced CD4-targeted entry inhibition is associated with increased neutralizing antibody susceptibility. J Virol 2009, 83:9577-9583.

82. Gorry PR, Taylor J, Holm GH, Mehle A, Morgan T, Cayabyab M, Farzan M, Wang H, Bell JE, Kunstman K, Moore JP, Wolinsky SM, Gabuzda D: Increased CCR5 affinity and reduced CCR5/CD4 dependence of a neurovirulent primary human immunodeficiency virus type 1 isolate. $J$ Virol 2002, 76:6277-6292.

83. Dunfee RL, Thomas ER, Gorry PR, Wang J, Taylor J, Kunstman K, Wolinsky SM, Gabuzda D: The HIV Env variant N283 enhances macrophage tropism and is associated with brain infection and dementia. Proc Natl Acad Sci USA 2006, 103:15160-15165.

84. Peters PJ, Bhattacharya J, Hibbitts S, Dittmar MT, Simmons G, Bell J, Simmonds P, Clapham PR: Biological analysis of human immunodeficiency virus type 1 R5 envelopes amplified from brain and lymph node tissues of AIDS patients with neuropathology reveals two distinct tropism phenotypes and identifies envelopes in the brain that confer an enhanced tropism and fusigenicity for macrophages. J Virol 2004, 78:6915-6926.

85. Parekh BS, Kennedy MS, Dobbs T, Pau CP, Byers R, Green T, Hu DJ, Vanichseni S, Young NL, Choopanya K, Mastro TD, McDougal JS: Quantitative detection of increasing HIV type 1 antibodies after seroconversion: a simple assay for detecting recent HIV infection and estimating incidence. AIDS Res Hum Retroviruses 2002, 18:295-307.

86. Parekh BS, Pau CP, Kennedy MS, Dobbs TL, McDougal JS: Assessment of antibody assays for identifying and distinguishing recent from long-term HIV type 1 infection. AIDS Res Hum Retroviruses 2001, 17:137-146.

87. McDougal JS, Pilcher CD, Parekh BS, Gershy-Damet G, Branson BM, Marsh K, Wiktor SZ: Surveillance for HIV-1 incidence using tests for recent infection in resource-constrained countries. Aids 2005, 19(Suppl 2):S25-30.

88. Lakhashe S, Tripathy S, Paranjape R, Bhattacharya J: Characterization of B/C recombinants of near full-length HIV type 1 from northeastern India with mosaics identical to ARE195FL but with a different ancestral origin. AIDS Res Hum Retroviruses 2008, 24:92-99.

89. Wei X, Decker JM, Liu H, Zhang Z, Arani RB, Kilby JM, Saag MS, Wu X, Shaw GM, Kappes JC: Emergence of resistant human immunodeficiency virus type 1 in patients receiving fusion inhibitor (T-20) monotherapy. Antimicrob Agents Chemother 2002, 46:1896-1905.

90. Li M, Gao F, Mascola JR, Stamatatos L, Polonis VR, Koutsoukos M, Voss G, Goepfert P, Gilbert P, Greene KM, Bilska M, Kothe DL, Salazar-Gonzalez JF, Wei X, Decker JM, Hahn BH, Montefiori DC: Human immunodeficiency virus type 1 env clones from acute and early subtype $B$ infections for standardized assessments of vaccine-elicited neutralizing antibodies. $J$ Virol 2005, 79:10108-10125.

doi:10.1186/1742-4690-7-76

Cite this article as: Ringe et al: Variations in autologous neutralization and CD4 dependence of b12 resistant HIV-1 clade C env clones obtained at different time points from antiretroviral naïve Indian patients with recent infection. Retrovirology 2010 7:76.

\section{Submit your next manuscript to BioMed Central and take full advantage of:}

- Convenient online submission

- Thorough peer review

- No space constraints or color figure charges

- Immediate publication on acceptance

- Inclusion in PubMed, CAS, Scopus and Google Scholar

- Research which is freely available for redistribution

Submit your manuscript at www.biomedcentral.com/submit
C Biomed Central 